\title{
Tuberculosis in London - the importance of homelessness, problem drug use and prison.
}

Story $\mathrm{A}^{1}$, Murad $\mathrm{S}^{2}$, Roberts $\mathrm{W}^{3}$, Verheyen $\mathrm{M}^{4}$ Hayward $\mathrm{AC}^{2}$, for the London Tuberculosis Nurses Network.

1. Tuberculosis Section, Respiratory Diseases Department, Centre for Infections, Health Protection Agency, United Kingdom

2. UCL Centre for Infectious Disease Epidemiology, Department of Primary Care and Population Sciences, University College London, London, United Kingdom/Camden Primary Care Trust

3. North East London TB Network

4. Research Centre for Health Studies, Buckinghamshire Chilterns University College, Buckinghamshire, United Kingdom

\section{Author for correspondence:}

Alistair Story

Tuberculosis Section, Respiratory Diseases Department

Centre for Infections - Health Protection Agency

61 Colindale Avenue

LONDON NW9 5EQ

United Kingdom

T: 02083277475

F: 02082007868

E: alistair.story@hpa.org.uk

\section{Key words}

Homeless persons

Patient non-adherence

Prisoners

Substance abuse

Tuberculosis 


\section{ABSTRACT}

Background: Tuberculosis control is founded on early case detection and complete treatment of disease. In the UK tuberculosis is concentrated in subgroups of the population in large urban centres. We sought to describe the impact of homelessness, imprisonment and problem drug use on tuberculosis control in London.

Methods: We conducted a cohort study of all tuberculosis patients in Greater London to determine the point prevalence of disease in different groups and examine risk factors for smear positivity, drug resistance, treatment adherence, loss to follow-up and use of directly observed therapy (DOT).

Results: Data were collected on 97\% (1941/1995) of eligible patients. The overall prevalence of tuberculosis was 27 per 100,000. Extremely high prevalence of tuberculosis was seen in homeless people living on the streets or in hostels (788/100,000), problem drug users $(354 / 100,000)$, and prisoners $(208 / 100,000)$. On multivariate analysis problem drug use was associated with smear positive disease (OR 2.2, $\mathrm{p}<0.001$ ), being part of a known outbreak of drug resistant tuberculosis (OR $3.5, \mathrm{p}=0.001)$ and loss to follow-up (OR 2.7, $\mathrm{p}<0.001)$. Imprisonment was associated with being part of the outbreak (OR 10.3, p<0.001) and poor adherence (OR 3.9, $\mathrm{p}<0.001)$. Homelessness was associated with infectious tuberculosis (OR 1.6, $\mathrm{p}=0.05)$, multidrug resistance $(\mathrm{OR} 2.1, \mathrm{p}=0.03)$, poor adherence $(\mathrm{OR} 2.5, \mathrm{p}<0.001)$ and loss to follow-up (OR 3.8, $\mathrm{p}<0.001)$.

In London homeless people, prisoners and problem drug users collectively comprise $17 \%$ of TB cases, $44 \%$ of smear positive drug resistant cases, $38 \%$ of poorly compliant cases and $44 \%$ of cases lost to follow-up. $15 \%$ of these patients start treatment on DOT but $46 \%$ end up on DOT.

Conclusions: High levels of infectious and drug resistant disease, poor adherence and loss to follow up care indicate that tuberculosis is not effectively controlled among homeless people, prisoners and problem drug users in London. 


\section{INTRODUCTION}

In the developed world tuberculosis is increasingly concentrated in subgroups of the population in large urban centres. Tuberculosis is a major public health problem in London. The capital saw an $11 \%$ increase in new reported cases between 2004 and 2005 and now accounts for $45 \%$ of all cases reported in England.[1] Rates of disease have doubled from 21.2 per 100,000 per year in 1987 to 47 per 100,000 per year in 2005. [1] A large outbreak of drug resistant tuberculosis in London, with over 220 linked cases, has disproportionately involved problem drug users, prisoners and the homeless, highlighting weak control among these groups.[2,3]

Tuberculosis control is based on early case detection and ensuring patients complete at least six months of regular treatment.[4] Failure to do this can lead to increased disease transmission, the development of drug resistance and relapse. Poor adherence is a major barrier to successful treatment.[5] In many countries this has led to Directly Observed Therapy (DOT) becoming the accepted standard of care for tuberculosis.[6] There is a lack of randomised controlled trial evidence to support universal DOT in low prevalence settings.[7] In the UK, DOT is recommended for patients who have been or are likely to be poorly adherent, $[4,8]$ however, there are limited data on risk factors for poor adherence and on how DOT is used in practice in the UK.

Homelessness, problem drug use and imprisonment affect patients' ability to access health care and to take treatment. Tuberculosis is known to be common in the homeless $[9,10]$ but the extent of the problem in prisoners and drug users and the effect of these social issues on adherence, loss to follow up, infectiousness and drug resistance has not been adequately described. Levels of imprisonment, drug use and homelessness are high in London with an estimated 10,000 single homeless people living on the streets or in hostels, [11,12] 70,000 problem drug users [13] and over 5000 prisoners at any one time.[14] We conducted a study including all tuberculosis patients in London to describe the impact of homelessness, imprisonment and problem drug use on control.

\section{METHODS}

Study design: cohort study including all tuberculosis patients living in London who were or should have been on treatment on 1st July 2003. We used the London tuberculosis register and local clinic records to identify eligible patients. Patients' case-managers used clinic and hospital records and their knowledge of the patient to complete data collection forms at baseline and again at 12 months. We excluded cases subsequently found not to have tuberculosis.

Homelessness was defined as living in direct access hostels or rough sleeping either ever or during the current treatment episode. Imprisonment was defined as any period of incarceration during the current treatment episode. Problem drug use was defined as injecting drug use or long duration/regular use of opiates, cocaine and or amphetamines. [15] 
Drug resistance was divided into multidrug resistance (resistant to at least isoniazid and rifampicin), isonaizid resistant strains that were part of the London outbreak (defined as patients resident in London at the time of their diagnosis with isolates of Mycobacterium tuberculosis resistant to isoniazid that had the outbreak restriction fragment length polymorphism (RFLP) pattern) [6] and isoniazid resistant strains that were not part of the outbreak. Smear positivity related to status at diagnosis. The main outcomes were poor adherence, loss to follow up and management with DOT. DOT was defined as treatment being observed by a health care worker or other responsible adult. We measured adherence during the first 2 months of treatment because the risk of developing resistance is greatest when the bacterial load is high. We defined poorly adherent patients as those who: admitted poor adherence; had inconsistent pill counts; negative urine tests; or who were switched to DOT or admitted to hospital due to poor adherence. Loss to follow up was defined as the patient being out of contact with services for at least two months without medication during the first six months of treatment. We also collected data on age, gender, foreign birth, ethnicity, problem alcohol use, mental health problems and previous tuberculosis.

\section{Analysis of data}

We calculated prevalence of disease per 100,000 population on $1^{\text {st }}$ July 2003 (and 95\% confidence intervals based on the Poisson distribution) for homeless people, problem drug users and prisoners and compared these with prevalence in different ethnic groups and in the foreign born and UK born populations. We obtained denominator data on the size of the populations at risk from published sources. [10, $11,12,16]$

We assessed the relationships between variables using univariate and multivariate analyses. Logistic regression analysis was used to calculate univariate odds ratios, 95\% confidence intervals and $\mathrm{p}$ values. Multiple logistic regression models (backwards elimination) were used to control for confounding using robust standard errors to account for clustering at clinic level. [17,18,19] All analyses were performed using STATA version 9. [20]

\section{RESULTS}

There were 1995 eligible patients giving an overall point prevalence on $1^{\text {st }}$ July 2003 of 27.1 per 100,000 (95\% CI 25.9-28.3) (Table 1). Baseline data were collected on 97\% (1941/1995) of eligible patients. Follow up data were available on $95 \%$ $(1841 / 1941)$ of these. Prevalence in the homeless was 788 per 100,000 (95\% CI 624982), in problem drug users was 354 per 100,000 (95\% CI 311-401) and in prisoners was 208 per 100,000 (95\% CI 104-373). The prevalence in the foreign born was 80 per 100,000 (95\% CI 76-84) and in recent migrants with less than 1 year in the UK was 148 per 100,000 (95\% CI 131-165) (Table 1). 
Table 1: Prevalence of tuberculosis in different population groups

\begin{tabular}{|l|l|l|l|}
\hline Patient characteristics & $\begin{array}{l}\text { Number } \\
\text { of cases }\end{array}$ & $\begin{array}{l}\text { Population } \\
\text { denominator }\end{array}$ & $\begin{array}{l}\text { Prevalence per } \\
\mathbf{1 0 0 , 0 0 0}(\mathbf{9 5 \%} \text { CI) }\end{array}$ \\
\hline Overall & 1941 & $7172091^{12}$ & $27.1(25.9-28.3)$ \\
\hline Age 0-14 & 92 & $1365377^{12}$ & $6.7(5.4-8.3)$ \\
\hline Age 15-29 & 718 & $1639963^{12}$ & $43.8(40.6-47.1)$ \\
\hline Age 30-59 & 919 & $2992305^{12}$ & $30.7(28.8-33.8)$ \\
\hline Age 60+ & 203 & $1174446^{12}$ & $17.3(15.0-19.8)$ \\
\hline Male & 1064 & $3468793^{12}$ & $30.7(28.9-32.6)$ \\
\hline Female & 847 & $3703298^{12}$ & $22.9(21.4-24.5)$ \\
\hline Foreign Born & 1548 & $1942904^{12}$ & $79.7(75.8-83.7)$ \\
\hline Born UK & 376 & $5229187^{12}$ & $7.2(6.5-8.0)$ \\
\hline Recent migrant (arrived $<1 \mathrm{yr})$ & 295 & $200000^{16}$ & $147.5(131.2-165.3)$ \\
\hline White & 303 & $5103203^{12}$ & $5.9(5.3-6.7)$ \\
\hline South Asian & 650 & $733635^{12}$ & $88.6(81.9-95.7)$ \\
\hline Black African & 748 & $378933^{12}$ & $197.4(183.5-212.1)$ \\
\hline Black Caribbean & 92 & $343567^{12}$ & $27.9(21.6-32.8)$ \\
\hline Other & 248 & $193235^{12}$ & $108.2(94.0-123.9)$ \\
\hline Problem Drug users & 79 & $70000^{12}$ & $354.3(311.4-401.2)$ \\
\hline Prison (on 1 st July 2003) & $5278^{12}$ & $208.4(104.1-372.9)$ \\
\hline Living in Hostel/on street & $10024^{12}$ & $788.1(624.0-982.2)$ \\
\hline
\end{tabular}

Six percent (110) of patients were homeless. Of these $42(38 \%)$ had infectious tuberculosis, and 30 of 77 culture confirmed cases (39\%) had drug resistant disease including five $(6.5 \%)$ with multidrug resistant disease. Fifty $(46 \%)$ were documented as being poorly adherent and 17 (16\%) lost to follow up. (Table 2) On multivariate analysis homelessness was associated with smear positive disease (OR 1.6, 95\% CI 1.0-2.6, $\mathrm{p}=0.05$ ), poor adherence (OR 2.5, 95\% CI 1.6-3.7 $\mathrm{p}<0.001$ ), and loss to follow up (OR 3.8, 95\% CI 1.9-7.4, $\mathrm{p}<0.001)$. Current or previous homelessness (ever homeless) was associated with MDRTB (OR 2.1, 95 CI 1.1-4.1, $\mathrm{p}=0.03$ ) (Table 3).

Thirteen percent (248) of patients were problem drug users. Amongst these 39\% (97) were smear positive, $8 \%$ (20) were confirmed as part of the London outbreak, $47 \%$ (116) were documented as poorly adherent and 25 (10\%) lost to follow up. (Table 2) On multivariate analysis problem drug use was associated with smear positive disease (OR 2.2, 95\% CI 1.6-2.9, p<0.001), being part of the London outbreak of isoniazid resistant tuberculosis (OR 3.5, 95\% CI 1.6-7.7, p=0.001) loss to follow up (OR 2.7, 95\% CI 1.6-4.3, p<0.001) (Table 3). 
Four percent (74) of patients were prisoners at some time during treatment. Of these $29(39 \%)$ of prisoners had smear positive disease, $19(26 \%)$ were confirmed as part of the London outbreak and $44(59 \%)$ were poorly adherent and $9(12 \%)$ who were lost to follow up. (Table 2) On multivariate analysis imprisonment was associated with being part of the London outbreak (OR 10.3, 95\% CI 4.0-26.5, p<0.001), poor adherence (OR 3.9, 95\% CI 2.5-6.1, p<0.001) (Table 3).

Overall $350(18 \%)$ of patients were non-adherent in the first two months of treatment. South Asians, females, recent migrants and foreign born cases were most likely to adhere to treatment. Patients least likely to adhere to treatment were homeless people, problem drug users and prisoners. Overall 177 (9.1\%) of patients started their treatment on DOT with $492(25.3 \%)$ eventually being treated with DOT. Relatively few homeless, prisoners or drug using patients started their treatment using DOT but most ended up being treated with DOT after demonstrating poor adherence (Figure 1).

Collectively drug users, the homeless and prisoners make up $17 \%(321 / 1941)$ of tuberculosis cases, 38\% (133/350) of poorly compliant cases, 44\% (29/66) of cases lost to follow up, 39\% (79/492) of cases ever treated with DOT, 30\% (115/381) of smear positive TB cases, 29\% (67/234) of drug resistant cases (Table 2) and 44\% (31/71)of smear positive drug resistant cases. There was a high degree of overlap between homeless, prison and drug using populations.(Figure 2) 
Table 2: Demographic, disease related and social characteristics

\begin{tabular}{|c|c|c|c|c|c|c|c|c|c|c|c|}
\hline \multirow[b]{2}{*}{$\begin{array}{l}\text { Patient } \\
\text { characteristics }\end{array}$} & \multirow[b]{2}{*}{$\mathrm{n}$} & \multicolumn{6}{|c|}{ Laboratory findings } & \multicolumn{4}{|c|}{ Management issues } \\
\hline & & $\begin{array}{l}\text { Culture } \\
\text { confirmed } \\
\mathrm{n}(\%)\end{array}$ & $\begin{array}{l}\text { Sputum smear } \\
\text { positive } \mathrm{n}(\%)\end{array}$ & $\begin{array}{l}\text { Any Drug } \\
\text { Resistance } \\
\mathrm{n}(\%)\end{array}$ & $\begin{array}{l}\text { MDRTB n } \\
(\%)\end{array}$ & $\begin{array}{l}\text { Isoniazid } \\
\text { resistant (non- } \\
\text { outbreak) } \\
\mathrm{n}(\%)\end{array}$ & $\begin{array}{l}\text { Isoniazid } \\
\text { (Outbreak) } \\
\mathrm{n}(\%)\end{array}$ & $\begin{array}{l}\text { Non-adherent } \\
\text { in first two } \\
\text { months } \\
\mathrm{n}(\%)\end{array}$ & $\begin{array}{l}\text { Loss to } \\
\text { follow-up } \\
\text { within } 6 \\
\text { months } \mathrm{n}(\%)\end{array}$ & $\begin{array}{l}\text { DOT from } \\
\text { start of } \\
\text { treatment } \\
\mathrm{n}(\%)\end{array}$ & $\begin{array}{l}\text { DOT ever } \\
\mathrm{n}(\%)\end{array}$ \\
\hline Overall & 1941 & $1121(57.8 \%)$ & $381(19.6 \%)$ & $234(20.9 \%)$ & $67(6.0 \%)$ & $129(11.5 \%)$ & $38(3.4 \%)$ & $350(18.0 \%)$ & $66(3.4 \%)$ & $177(9.1 \%)$ & $492(25.3 \%)$ \\
\hline Age 0-14 & 92 & $29(31.5 \%)$ & $5(5.4 \%)$ & $6(20.6 \%)$ & $2(6.9 \%)$ & $3(10.3 \%)$ & $1(3.4 \%)$ & $8(8.7 \%)$ & $1(1.1 \%)$ & $34(37.0 \%)$ & $56(60.9 \%)$ \\
\hline Age 15-29 & 718 & $444(61.8 \%)$ & $158(22.0 \%)$ & $97(21.8 \%)$ & $27(6.1 \%)$ & $57(12.8 \%)$ & $13(2.9 \%)$ & $138(19.2 \%)$ & $31(4.3 \%)$ & $39(5.4 \%)$ & $143(19.9 \%)$ \\
\hline Age 30-59 & 919 & $536(58.3 \%)$ & $187(20.3 \%)$ & $116(21.6 \%)$ & $32(6.0 \%)$ & $61(11.4 \%)$ & $23(4.3 \%)$ & $169(18.4 \%)$ & $29(3.2 \%)$ & $78(8.5 \%)$ & $215(23.4 \%)$ \\
\hline Age 60+ & 203 & $108(53.2 \%)$ & $31(15.3 \%)$ & $13(12.0 \%)$ & $5(4.6 \%)$ & $7(6.5 \%)$ & $1(0.9 \%)$ & $34(16.7 \%)$ & $5(2.5 \%)$ & $26(12.8 \%)$ & $76(37.4 \%)$ \\
\hline Male & 1064 & $637(59.9 \%)$ & $231(21.7 \%)$ & $139(21.8 \%)$ & $41(6.4 \%)$ & $74(11.6 \%)$ & $24(3.8 \%)$ & $231(21.7 \%)$ & $49(4.6 \%)$ & $97(9.1 \%)$ & $278(26.1 \%)$ \\
\hline Female & 847 & $467(55.1 \%)$ & $147(17.4 \%)$ & $94(20.1 \%)$ & $26(5.6 \%)$ & 54 (11.6) & $14(3.0 \%)$ & $115(13.6 \%)$ & $17(2.0 \%)$ & $79(9.3 \%)$ & $210(24.8 \%)$ \\
\hline Foreign Born & 1548 & $902(58.3 \%)$ & $227(14.7 \%)$ & $179(19.8 \%)$ & $59(6.5 \%)$ & $106(11.8 \%)$ & $14(1.6 \%)$ & $272(17.6 \%)$ & $47(3.0 \%)$ & $110(7.1 \%)$ & $339(21.9 \%)$ \\
\hline Born UK & 376 & $206(54.8 \%)$ & $100(26.6 \%)$ & $52(25.2 \%)$ & $6(2.9 \%)$ & $23(11.2 \%)$ & $23(11.2 \%)$ & $74(19.7 \%)$ & $18(4.8 \%)$ & $67(17.8 \%)$ & $149(39.6 \%)$ \\
\hline $\begin{array}{l}\text { Recent migrant } \\
(<1 \mathrm{yr})\end{array}$ & 295 & $172(58.3 \%)$ & $54(18.3 \%)$ & $30(17.4 \%)$ & $10(5.8 \%)$ & $19(11.0 \%)$ & $1(0.6 \%)$ & $50(16.9 \%)$ & $8(2.7 \%)$ & $19(6.4 \%)$ & $53(18.0 \%)$ \\
\hline White & 303 & $188(62.0 \%)$ & $85(28.1 \%)$ & $34(18.1 \%)$ & $6(3.2 \%)$ & $19(10.0 \%)$ & $9(4.8 \%)$ & $70(23.1 \%)$ & $13(4.3 \%)$ & $49(16.2 \%)$ & $115(38.0 \%)$ \\
\hline South Asian & 650 & $339(52.2 \%)$ & $79(12.2 \%)$ & $52(15.3 \%)$ & $16(4.7 \%)$ & $33(9.7 \%)$ & $3(0.9 \%)$ & $84(12.9 \%)$ & $20(3.1 \%)$ & $33(5.1 \%)$ & $124(19.1 \%)$ \\
\hline Black African & 748 & $449(60.0 \%)$ & $150(20.1 \%)$ & $100(22.3 \%)$ & $37(8.2 \%)$ & $59(13.1 \%)$ & $4(0.9 \%)$ & $147(19.7 \%)$ & $24(3.2 \%)$ & $60(8.0 \%)$ & $177(23.7 \%)$ \\
\hline Black Caribbean & 92 & $64(69.6 \%)$ & $33(35.9 \%)$ & $25(39.1 \%)$ & $2(3.2 \%)$ & $6(9.4 \%)$ & $17(26.6 \%)$ & $27(29.3 \%)$ & $3(3.2 \%)$ & $19(20.7 \%)$ & $36(39.1 \%)$ \\
\hline Other & 83 & $48(57.8 \%)$ & $19(22.9 \%)$ & $15(31.3 \%)$ & $5(10.4 \%)$ & $8(16.7 \%)$ & $2(4.2 \%)$ & $12(14.5 \%)$ & $4(4.8 \%)$ & $8(9.6 \%)$ & $20(24.1 \%)$ \\
\hline Previous TB & 202 & $111(55.0 \%)$ & $42(20.8 \%)$ & $47(42.3 \%)$ & $26(23.4 \%)$ & $15(13.5 \%)$ & $6(5.4 \%)$ & $64(31.7 \%)$ & $17(8.4 \%)$ & $28(13.9 \%)$ & $79(39.1 \%)$ \\
\hline $\begin{array}{l}\text { Problem Drug users } \\
\text { (PDU) }\end{array}$ & 248 & $176(71.0 \%)$ & $97(39.1 \%)$ & $58(33.0 \%)$ & $11(6.3 \%)$ & $20(11.4 \%)$ & $27(15.3 \%)$ & $116(46.8 \%)$ & $25(10 \%)$ & $41(16.5 \%)$ & $119(48.0 \%)$ \\
\hline Alcohol & 156 & $111(71.2 \%)$ & $64(41.0 \%)$ & $34(30.6 \%)$ & $5(4.5 \%)$ & $11(9.9 \%)$ & $18(16.2 \%)$ & $82(52.6 \%)$ & $17(10.8 \%)$ & $33(21.2 \%)$ & $84(53.84 \%)$ \\
\hline $\begin{array}{l}\text { Prison during } \\
\text { treatment }\end{array}$ & 74 & $55(74.3 \%)$ & $29(39.2 \%)$ & $30(54.5 \%)$ & $8(14.5 \%)$ & $3(5.5 \%)$ & $19(34.5 \%)$ & $44(59.5 \%)$ & $9(12.1 \%)$ & $15(20.3 \%)$ & $54(72.97 \%)$ \\
\hline $\begin{array}{l}\text { Homeless during } \\
\text { treatment }\end{array}$ & 110 & $77(70.0 \%)$ & $42(38.2 \%)$ & $30(39.0 \%)$ & $5(6.5 \%)$ & $13(16.9 \%)$ & $12(15.6 \%)$ & $50(45.5 \%)$ & $17(15.4 \%)$ & $21(19.1 \%)$ & $65(59.09 \%)$ \\
\hline $\begin{array}{l}\text { Prison OR Homeless } \\
\text { OR PDU }\end{array}$ & 321 & $221(68.8 \%)$ & $115(35.8 \%)$ & $67(30.3 \%)$ & $14(6.3 \%)$ & $26(11.8 \%)$ & $27(12.2 \%)$ & $133(41.4 \%)$ & $29(9 \%)$ & $48(15.0 \%)$ & $146(45.48 \%)$ \\
\hline
\end{tabular}


Table 3: Multivariate associations between patient characteristics and: infectivity; drug resistance and treatment adherence - OR ( $95 \% \mathrm{CI}) p$

\begin{tabular}{|c|c|c|c|c|c|c|c|c|c|}
\hline & \multicolumn{5}{|c|}{ Laboratory findings } & \multicolumn{4}{|c|}{ Management issues } \\
\hline & $\begin{array}{l}\text { Sputum smear } \\
\text { positive }\end{array}$ & $\begin{array}{l}\text { Any Drug } \\
\text { resistance }\end{array}$ & MDRTB & $\begin{array}{l}\text { Isoniazid } \\
\text { resistant (non- } \\
\text { outbreak) }\end{array}$ & $\begin{array}{l}\begin{array}{l}\text { Isoniazid } \\
\text { resistant } \\
\text { (outbreak) }\end{array} \\
\end{array}$ & $\begin{array}{l}\text { Non-adherent in } \\
\text { the first two } \\
\text { months }\end{array}$ & $\begin{array}{l}\text { Loss to follow } \\
\text { up within } 6 \\
\text { months }\end{array}$ & $\begin{array}{l}\text { DOT from start } \\
\text { of treatment }\end{array}$ & DOT ever \\
\hline Age 0-14 & $0.3(0.1-0.8)$ & $1.0(0.3-3.4)$ & & $0.8(0.2-4.6)$ & & $0.6(0.2-1.4)$ & $0.6(0.8-4.7)$ & $9.2(3.3-25.6)$ & $8.2(3.2-20.6)$ \\
\hline Age 15-29 & $1.3(1.0-1.7)$ & $1.1(0.8-1.6)$ & & $1.1(0.7-1.7)$ & & $1.2(0.9-1.7)$ & $1.7(1-2.9)$ & $0.8(0.5-1.4)$ & $1.0(0.8-1.3)$ \\
\hline Age 30-59 & $1(\mathrm{p}=0.008)$ & $1(\mathrm{p}=0.22)$ & & $1(\mathrm{p}=0.41)$ & & $1(\mathrm{p}=0.32)$ & $1(\mathrm{p}=0.24)$ & $1(\mathrm{p}<0.001)$ & $1(\mathrm{p}<0.001)$ \\
\hline Age 60+ & $0.7(0.4-1.3)$ & $0.6(0.4-1.0)$ & & $0.5(0.3-1.2)$ & & $1.1(0.8-1.6)$ & $1.2(0.5-2.9)$ & $1.8(0.8-3.7)$ & $2.7(1.7-4.4)$ \\
\hline Male & $\begin{array}{l}1.1(0.8-1.5) \\
(\mathrm{p}=0.38)\end{array}$ & $\begin{array}{l}1.0(0.7-1.4) \\
(\mathrm{p}=0.89)\end{array}$ & & $\begin{array}{l}1.0(0.7-1.6) \\
(\mathrm{p}=0.90)\end{array}$ & & $\begin{array}{l}1.6(1.3-2.0) \\
(\mathrm{p}=<0.001)\end{array}$ & $\begin{array}{l}1.9(1.2-3.0) \\
(\mathrm{p}=0.006)\end{array}$ & $\begin{array}{l}0.8(0.6-1.2) \\
(\mathrm{p}=0.33)\end{array}$ & $\begin{array}{l}0.9(0.7-1.1) \\
(\mathrm{p}=0.21)\end{array}$ \\
\hline Born UK & & & & & $\begin{array}{l}2.8(1.1-7.0) \\
(\mathrm{p}=0.03)\end{array}$ & & & & \\
\hline White & $1(\mathrm{p}<0.001)$ & $1(\mathrm{p}<0.021)$ & $1(\mathrm{p}=0.19)$ & $1(\mathrm{p}=0.21)$ & $1(\mathrm{p}<0.001)$ & $1(\mathrm{p}=0.03)$ & $1(\mathrm{p}=0.21)$ & $1(\mathrm{p}<0.13)$ & $1(\mathrm{p}=0.26)$ \\
\hline South Asian & $0.4(0.3-0.6)$ & $1.0(0.6-1.6)$ & $1.6(0.8-3.0)$ & $1.0(0.5-2.1)$ & $1.1(0.2-6.7)$ & $0.7(0.5-1.1)$ & $1.5(0.7-3.0)$ & $0.4(0.2-0.9)$ & $0.6(0.4-1.0)$ \\
\hline Black African & $0.8(0.5-1.1)$ & $1.3(0.8-2.0)$ & $2.5(1.2-5.7)$ & $1.4(0.7-2.6)$ & $0.8(0.1-7.2)$ & $1.1(0.8-1.6)$ & $1.3(0.7-2.6)$ & $0.5(0.3-1.0)$ & $0.7(0.5-1.1)$ \\
\hline $\begin{array}{l}\text { Black } \\
\text { Caribbean }\end{array}$ & $1.5(1.0-2.1)$ & $3.0(1.2-7.7)$ & $1.6(0.3-10.2)$ & $1.5(0.5-5.2)$ & $9.7(2.6-35.4)$ & $1.4(0.9-2.3)$ & $0.7(0.3-1.9)$ & $1.0(0.5-2.1)$ & $0.7(0.4-1.6)$ \\
\hline Other ethnic & $1.0(0.7-1.4)$ & $1.9(1.0-3.4)$ & $2.5(0.9-7.1)$ & $1.8(0.7-4.2)$ & $6.1(1.6-23.3)$ & $0.8(0.5-1.3)$ & $2.1(0.9-4.9)$ & $0.7(0.3-1.6)$ & $0.9(0.6-1.6)$ \\
\hline Previous TB & & $\begin{array}{l}3.0(1.9-4.9) \\
(p=<0.001)\end{array}$ & $\begin{array}{l}7.8(4.8-12.5) \\
(p=<0.001)\end{array}$ & & & & & & \\
\hline $\begin{array}{l}\text { Problem Drug } \\
\text { users }\end{array}$ & $\begin{array}{l}2.2(1.6-2.9) \\
(\mathrm{p}=<0.001)\end{array}$ & & & & $\begin{array}{l}3.5(1.6-7.7) \\
(\mathrm{p}=0.001)\end{array}$ & & $\begin{array}{l}2.7(1.6-4.3) \\
(p=<0.001)\end{array}$ & $\begin{array}{l}1.6(0.8-2.9) \\
(\mathrm{p}=0.17)\end{array}$ & $\begin{array}{l}2.0(1.2-3.2) \\
(\mathrm{p}=0.004)\end{array}$ \\
\hline $\begin{array}{l}\text { Prison in this } \\
\text { episode }\end{array}$ & & $\begin{array}{l}3.0(1.7-5.5) \\
(\mathrm{p}=<0.001)\end{array}$ & & & $\begin{array}{l}10.3(4.0-26.5) \\
(\mathrm{p}=<0.001)\end{array}$ & $\begin{array}{l}3.9(2.5-6.1) \\
(\mathrm{p}=<0.001)\end{array}$ & & & $\begin{array}{l}5.1(2.6-10.3 \\
(\mathrm{p}=<0.001)\end{array}$ \\
\hline $\begin{array}{l}\text { Hostel / street } \\
\text { homeless }\end{array}$ & $\begin{array}{l}1.6(1.0-2.6) \\
(\mathrm{p}=<0.054)\end{array}$ & & & $\begin{array}{l}2.0(0.9-4.5) \\
(\mathrm{p}=0.09)\end{array}$ & & $\begin{array}{l}2.5(1.6-3.7) \\
(p=<0.001)\end{array}$ & $\begin{array}{l}3.8(2.0-7.4) \\
(\mathrm{p}=<0.001)\end{array}$ & $\begin{array}{l}1.6(0.8-3.1) \\
(\mathrm{p}=0.16)\end{array}$ & $\begin{array}{l}2.6(1.7-3.9) \\
(\mathrm{p}=<0.001)\end{array}$ \\
\hline Ever homeless & & $\begin{array}{l}1.6(1.1-2.2) \\
(\mathrm{p}=<0.015)\end{array}$ & $\begin{array}{l}2.1(1.1-4.1) \\
(\mathrm{p}=0.028)\end{array}$ & & & & & & \\
\hline $\begin{array}{l}\text { Mental health } \\
\text { problem }\end{array}$ & & & & & & $\begin{array}{l}2.1(1.3-3.3) \\
(\mathrm{p}=0.003)\end{array}$ & $\begin{array}{l}2.1(1.0-4.7) \\
(\mathrm{p}=<0.049)\end{array}$ & $\begin{array}{l}3.1(1.5-6.3) \\
(\mathrm{p}=0.002)\end{array}$ & $\begin{array}{l}4.3(2.5-7.3) \\
(\mathrm{p}=<0.001)\end{array}$ \\
\hline
\end{tabular}

Table 3 includes adjusted Odds Ratios for variables that remained in the regression model following backwards elimination. 


\section{DISCUSSION}

The study demonstrates that tuberculosis is a major public health problem in London and particularly among homeless people, prisoners and problem drug users. These patients have high prevalence of disease and are often infectious, drug resistant, poorly adherent and lost to follow up. They form only $17 \%$ of all cases but nearly half of all drug resistant smear positive patients making a disproportionate impact on control.

Ascertainment of risk factors such as homelessness, drug use and prison history can be difficult. Although we provided clear case definitions it is likely that we have underestimated the extent of these problems. Estimating the numbers of homeless people and problem drug users in London is also problematic. The reliability of prevalence estimates is also dependent on denominator data. We relied on published estimates of population sizes in London. Measuring poor adherence is notoriously difficult. We relied on hard measures and are therefore likely to have under ascertained poor adherence.

We achieved a high level of completeness for baseline and follow up data by working closely with patients' case managers who were highly knowledgeable about their patients. This allowed detailed information on social circumstances that is not normally systematically recorded to be collected with a high degree of accuracy. Collection of data on multiple risk factors enabled confounding to be adequately controlled. The size and pan-London nature of the study are major strengths. Although the study was confined to London similar issues are likely to be seen in any cities with large homeless, drug using and prison populations.

Previous studies in the United States have demonstrated homeless people, prisoners and drug users as having high rates of infection, active disease, poor treatment outcomes and to be associated with recent transmission and outbreaks. [21,22,23,24] These studies have also demonstrated high levels of overlap between these populations. The contribution of homelessness, imprisonment and problem drug use to tuberculosis in the UK context has not been previously described. Data on these factors are not routinely collected. This study confirms these factors as being of major importance in London, quantifies the prevalence of disease in these populations, and shows that homelessness, prison and problem drug use are independent risk factors for drug resistance, smear positivity and poor adherence. Any of these factors either alone or in combination should raise the index of suspicion for tuberculosis, alert health professionals to the possibility of drug resistance and infectiousness and the need to instigate measures that will help patients to complete treatment.

Homeless people, problem drug users and prisoners, commonly share overcrowded, poorly ventilated spaces leading to a high risk of transmission as illustrated by the current large outbreak of drug resistant tuberculosis in London. In addition to large outbreaks molecular epidemiological research in the Netherlands has demonstrated intense transmission among drug addicts and homeless people by multiple sources. [25] High levels of sputum smear positivity on diagnosis amongst homeless people, problem drug users and prisoners are likely to indicate delays in case detection. The duration of infectiousness is a key parameter for the transmission of any infectious disease.[26] There is a need to evaluate measures to promote early case detection including raising awareness, improving access to services and active case finding measures such as mobile X-ray screening. [27]

In the United States $86 \%$ of homeless patients between 1994 and 2003 were treated using DOT. Those treated in this way had higher levels of treatment completion.[19] In London in 2003 only $12 \%$ of homeless patients started their treatment under direct observation but a further $47 \%$ were 
later switched to DOT after demonstrating poor adherence. Similar figures were seen for prisoners and problem drug users. This is despite national guidance since 1998 [28] that "DOT is recommended for patients who are unlikely to comply" and most recently in 2006 the National Institute of Health and Clinical Excellence (NICE) recommended that "all patients should have a risk assessment for adherence to treatment, and DOT should be considered for patients who have adverse factors on their risk assessment; in particular street- or shelter-dwelling homeless people and prisoners with active TB and patients with likely poor adherence and those who have a history of non-adherence”. [8]

Greater emphasis is needed on practical measures to identify patients at risk of poor treatment adherence early and provide additional support including DOT from the start of treatment, access to appropriate accommodation, and use of incentives.[29, 30, 31] DOT is unlikely to lead to improved treatment outcomes unless initiated in conjunction with a package of supportive care tailored to patients' needs. [8, 32, 33]

Most tuberculosis patients pose a minimal transmission risk as they are smear negative on diagnosis, demonstrate good adherence to treatment and have high rates of treatment completion. By contrast, high levels of infectious and drug resistant disease, poor adherence and loss to follow up indicate that tuberculosis is not effectively controlled among homeless people, prisoners and problem drug users in London.

\section{ACKNOWLEDGEMENTS}

All TB nurses, allied professionals and administrative staff in London who contributed data. Dr John Watson, Professor Anne Johnson and Dr Rob van Hest for comments on the manuscript. The London Infectious Disease Research Network for support with ethical applications and analysis.

Competing interests: none.

Funding: The Department of Health and The Health Protection Agency

Ethics approval: London Metropolitan Multi-centre Research Ethics Committee

Statement of independence of researchers from funders - Alistair Story is currently employed by the Health Protection Agency

\section{Licence}

The Corresponding Author has the right to grant on behalf of all authors and does grant on behalf of all authors, an exclusive licence (or non exclusive for government employees) on a worldwide basis to the BMJ Publishing Group Ltd and its Licensees to permit this article (if accepted) to be published in [THORAX] editions and any other BMJPG Ltd products to exploit all subsidiary rights, as set out in our licence (http://thorax.bmjjournals.com/ifora/licence.pdf) 


\section{REFERENCES:}

1) Health Protection Agency. Focus on Tuberculosis: Annual surveillance report 2005 - England, Wales and Northern Ireland. London: Health Protection Agency Centre for Infections. December 2006.

2) Isoniazid mono-resistant tuberculosis in north London - update. CDR Weekly: Volume 16 Number 9: 2 March 2006

3) Ruddy MC, Davies AP, Yates MD et al. Outbreak of isoniazid resistant tuberculosis in north London. Thorax 2004; 59(4):279-85

4) Stopping Tuberculosis in England: An action plan from the Chief Medical Officer http://www.dh.gov.uk/PublicationsAndStatistics/Publications/PublicationsPolicyAndGuidance/PublicationsPol icyAndGuidanceArticle/fs/en?CONTENT_ID=4090417\&chk=DsgbSP. October 2004, Department of Health.

5) Burman WJ, Cohn DL, Rietmeijer CA, Judson FN, Sbarbaro JA, Reves RR. Noncompliance with directly observed therapy for tuberculosis. Epidemiology and effect on the outcome of treatment. Chest 1997;111:1168-73.

6) Dye C, Watt CJ, Bleed DM, Hosseini SM, Raviglione MC. Evolution of tuberculosis control and prospects for reducing tuberculosis incidence, prevalence, and deaths globally. JAMA. 2005 Jun 8;293(22):2767-75

7) Volmink J, Garner P. Directly observed therapy for treating tuberculosis.Cochrane Database Syst Rev. 2006 Apr 19;(2):CD003343.

8) National Institute for Health and Clinical Excellence. Tuberculosis. Clinical diagnosis and management of tuberculosis, and measures for its prevention and control. London: NICE, March 2006. www.nice.org.uk/page.aspx?o=296657 (accessed 5 Jan 2007).

9) Kumar D, Citron KM, Leese $\mathbf{J}$ et al. Tuberculosis among the homeless at a temporary shelter in London: a report of chest X-ray screening programme. J Epidemiol Community Health 1995;49:629-33

10) Southern A, Premaratne N, English M et al. Tuberculosis among homeless people in London: an effective model of screening and treatment. Int J Tuberc Lung Dis 1999;3 (11):1001-8

11) Sycamore R. An Overview of Homelessness in London. Homeless Link. 2002

12) National Statistics, 2001 Census information. Office for National Statistics. London 2003. (Accessed 27 January 2006 http://www.lho.org.uk/viewResource.aspx?id=7923)

13) Greater London Alcohol and Drug Alliance London: The highs and the lows Greater London Authority February 2003 (Accessed on 24 March 2006

http://www.london.gov.uk/mayor/health/drugs_and_alcohol/docs/highs-lows-exec-sum.rtf)

14) Prison Statistics England and Wales 2002. National Statistics. (Accessed 27 January 2006 http://www.official-documents.co.uk/document/cm59/5996/5996.pdf )

15) Annual report 2003. The state of the drugs problem in the European Union and Norway. European Monitoring Centre for Drugs and Drug Addiction, 2003. (Accessed 27 January 2006 http://ar2003.emcdda.eu.int/en/homeen.html )

16) International Migration - Migrants entering or leaving England and Wales 2001. Office for National Statistics. Series MN No.28 (Accessed 27 January 2006 http://www.statistics.gov.uk/downloads/theme_population/MN28.pdf )

17) Huber PJ, (1967) The behaviour of maximum likelihood estimates under non-standard conditions. In Proceedings of the fifth Berkeley Symposium on Mathematical Statistics and Probability. Berkeley: University of California Press, 1, 221-233.

18) White $\mathrm{H}, \mathrm{A}$ heteroskedasticity-consistent covariance matrix estimator and a direct test for heteroskedasticity. Econometrica. 1980; 48: 817-830.

19) -- Maximum likelihood estimation of misspecified models Econometrica 1982; 50: 1-25

20) STATA version 9, (2005) STATA Corp. LP. College Station, Tx, USA

21) Haddad MB, Wilson TW, Ijaz K, Marks SM, Moore M. Tuberculosis and homelessness in the United States, 1994-2003. JAMA. 2005 Jun 8;293(22):2762-6.

22) Moss AR, Hahn JA, Tulsky JP et al. Tuberculosis in the homeless. A prospective study. Am J Respir Crit Care Med 2000;162 (2):460-4

23) Salomon N, Perlman DC, Friedmann P et al. Prevalence and risk factors for positive tuberculin skin tests among active drug users at a syringe exchange program. Int J Tuberc Lung Dis 2000;4(1):47-54

24) Chaves F, Dronda F, Cave MD et al. A longitudinal study of transmission of tuberculosis in a large prison population. Am J Respir Crit Care Med 1997;155(2):719-25

25) de Vries G, van Hest RA. From contact investigation to tuberculosis screening of drug addicts and homeless persons in Rotterdam. Eur J Public Health. 2005 Oct 17; 1101-1262

26) RM Anderson, RM May Infectious diseases of humans: dynamics and control. 1991 Oxford University Press

27) Golub JE, Mohan CI, Comstock GW, Chaisson RE. Active case finding of tuberculosis: historical perspective and future prospects. Int J Tuberc Lung Dis. 2005 Nov;9(11):1183-203

28) Chemotherapy and Management of Tuberculosis in the United Kingdom: Recommendations 1998. Joint

Tuberculosis Committee of the British Thoracic Society. Thorax 1998; 53: 7: 536-548 
29) Pablos-Mendez A, Knirsch CA, Barr RG et al. Nonadherence in tuberculosis treatment: predictors and consequences in New York City. Am J Med 1997;102(2):164-70

30) LoBue PA, Cass R, Lobo D et al. Development of housing programs to aid in the treatment of tuberculosis in homeless individuals: a pilot study. Chest 1999;115(1):218-23

31) Bock NN, Sales RM, Rogers T et al. A spoonful of sugar...:improving adherence to tuberculosis treatment using financial incentives. Int J Tuberc Lung Dis 2001;5(1):96-8.

32) Volmink J, Matchaba P, Garner P. Directly observed therapy and treatment adherence. Lancet 2000;355:134550.

33) Sumartojo E. When tuberculosis treatment fails: a social behavioural account of patient adherence. Am Rev Respir Dis 1993;147:1311-20. 
Figure 1: Proportion of patients with DOT from onset, non-adherent in the first two months of treatment and treated with DOT at any point of treatment [ordered by risk of non-adherence]

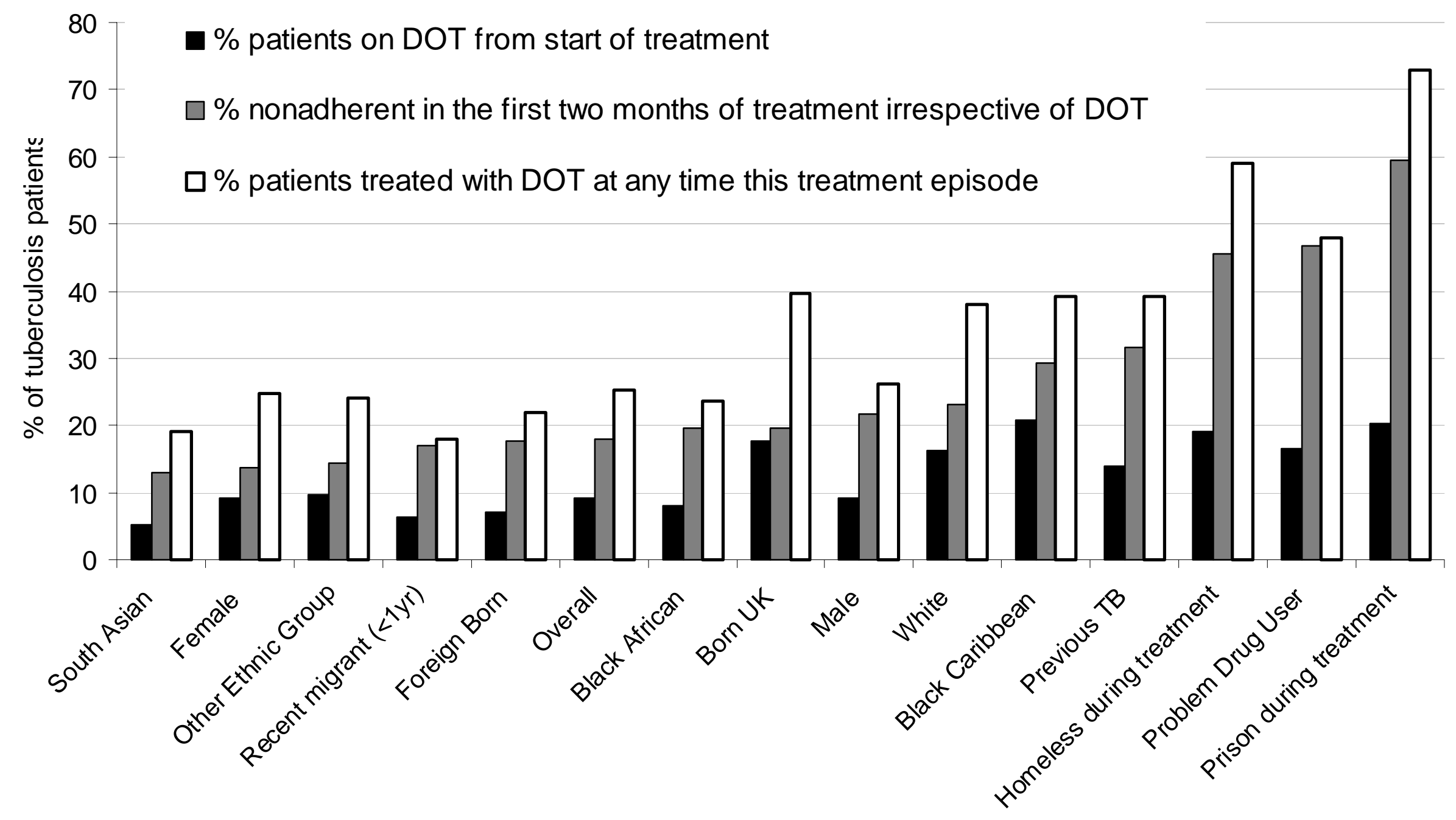


Figure 2: Overlap between prison, drug using and homeless populations amongst tuberculosis patients in London (not to scale).

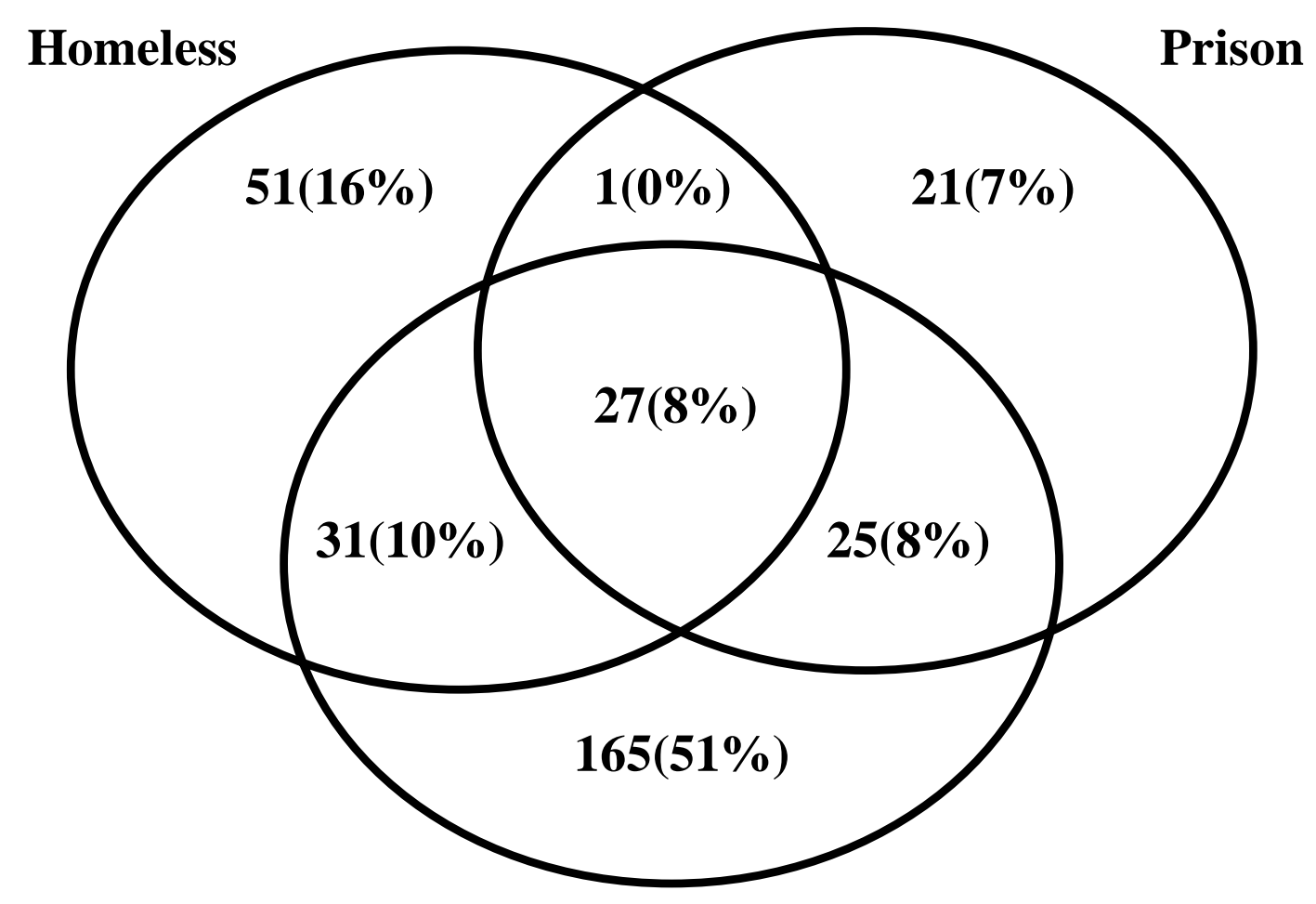

Problem drug use 